Original article

\title{
Evaluation of toxicity of 'Vatsanabha' (Aconitum ferox, Ranunculaceae) Before and After Shodhana
}

\author{
S.L. Deore*, K.V. Moon, S.S. Khadabadi, U.A. Deokate, B.A. Baviskar \\ Department of Pharmacognosy \& Phytochemistry, Government College of Pharmacy, Kathora Naka, Amravati (M.S.), India
}

\section{A R T I C L E I N F O}

\section{Article history:}

Received 25 July 2012

Accepted 14 December 2012

Available online 7 March 2013

\section{Keywords:}

Aconitine

Shodhana

Toxicity

\begin{abstract}
A B S T R A C T
Ayurvedic preparations contain toxic elements like heavy metals and other chemicals exceeding their permissible limits. Ayurvedic method of detoxification of such products involves Shodhana. Hence, in present paper it has been decided to replace Ayurvedic Shodhana process by chemical purification method and to study the benefits and/or drawbacks of the traditional Ayurvedic Shodhana process. Crude aconite root, Ayurvedic Shodhana treated aconite root and chemical Shodhana treated aconite root samples were evaluated for toxicity and changes by animal studies and thin layer chromatography (TLC) respectively. The results of the toxicity study suggest that the modified method of Shodhana is less efficient as compared to the traditional Ayurvedic Shodhana process. TLC studies have shown that pseudoaconitine and aconitine were converted into far less toxic substances like veratroyl pseudoaconine and benzoylaconine respectively only in traditional Ayurvedic Shodhana.
\end{abstract}

Copyright (c) 2013, InPharm Association, Published by Reed Elsevier India Pvt. Ltd. All rights reserved.

\section{Introduction}

In Ayurveda, the very first stage of purification is called Shodhana. ${ }^{1}$ Chemical purification is different from this purification. In chemical purification, there is only elimination of foreign matter, however, Shodhana eliminates harmful matter, modifies or converts undesirable properties to desirable, enhanced therapeutic actions. By Shodhana, only toxic constituents from plants are either removed or made less toxic before their use in the formulation. However the Shodhana process requires treatment of such products with cow dung, cow urine, and cow milk, requires sunlight and special containers like Dolayantra. ${ }^{1}$ This may not always be feasible and/or acceptable to the consumer. Also, the quality and safety of the product After Shodhana is not assured because of lack of standardization of the traditional method. Shodhana is also a lengthy and time-consuming process. Hence, there is a need to develop an alternative chemical detoxification method to give the same result as that of the traditional Ayurvedic process, which can be performed easily and is acceptable to consumers. The method to be developed should also be able to assure quality and permit standardization of the processed products. The objective of present study is to develop a chemical lab-scale method and to compare it with the traditional Ayurvedic Shodhana process.

\footnotetext{
* Corresponding author.

E-mail address: sharudeore_2@yahoo.com (S.L. Deore).
}

\section{Materials and methods}

\subsection{Plant material}

The roots of Aconitum ferox (Fig. 1A) were powdered in a mixergrinder. The powder of root is packed in a paper bags and stored in an air-tight container until use.

\subsection{Shodhana by Ayurvedic method}

The roots of $A$. ferox were cut into small pea-sized pieces and kept in earthen pot containing cow urine for 8 days, and on each day, cow urine was changed for 7 days. On the 8th day, cow urine was not changed. The earthen pot was kept in sunlight (Fig. 1B). Then, it was washed with cold water, the upper layer was taken out, and was again washed with warm water. The pieces of drug were dried immediately by exposing them to sunlight. The dried pieces were grinded to get the powder form.

\subsection{Chemical composition of lab-prepared cow urine}

Water - 95\%; urea - 2.5\%; minerals (nitrogen, sulfur, phosphate, sodium, manganese, carbolic acid, iron, chlorine, magnesium) and hormones (corticosteroids) - 1\%; salts (malic, citric, tartaric, 

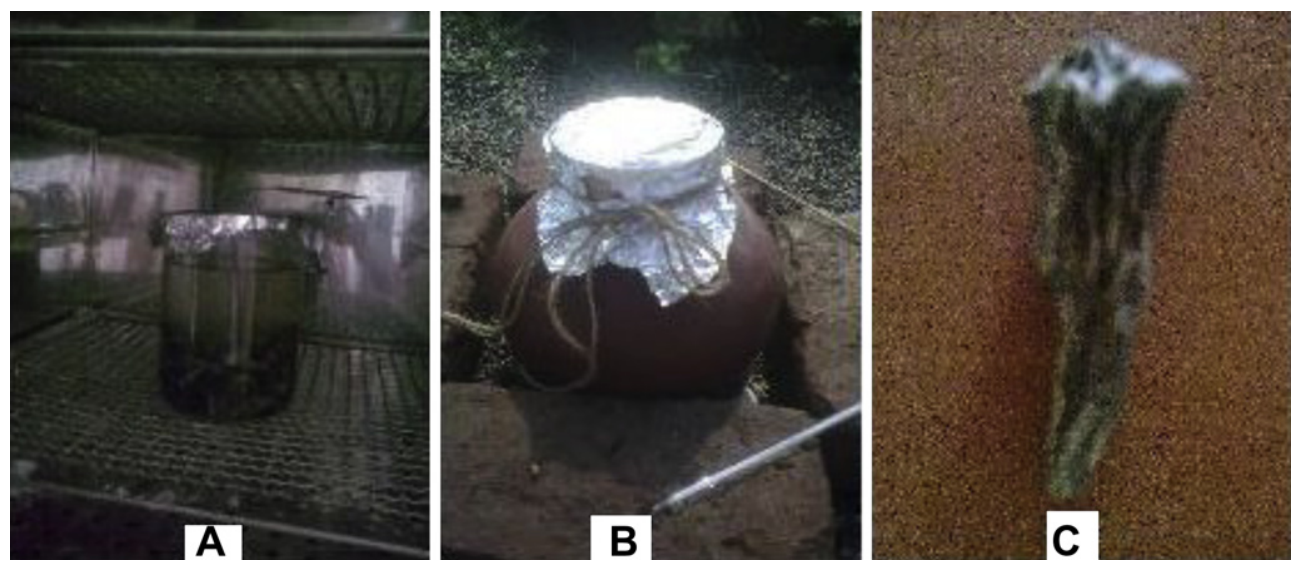

Fig. 1. (A) Aconite root. (B) Ayurvedic Shodhana process. (C) Chemical Shodhana process.

succinic, hippuric acids, calcium salts) and enzymes (urokinase) $1.5 \%$; vitamin $\mathrm{A}, \mathrm{B}, \mathrm{C}, \mathrm{D}, \mathrm{E}$, lactose, and creatinine $-0.5 \%$.

\subsection{Shodhana by modified chemical method}

The roots of $A$. ferox were cut into small pea-sized pieces of and kept in a glass beaker containing 11 laboratory-prepared solution of cow urine ${ }^{2}$ for 7 days. The solution was changed every day. The beaker was kept in an oven and the temperature was maintained at $37.5^{\circ} \mathrm{C}$ (Fig. 1C). Then, it was washed with cold water. The outer shell was removed, and washed again with warm water. The pieces were dried and ground to get the powder form. The $\mathrm{pH}$ of the solution was maintained at 8-8.5.

\subsection{Extraction of untreated A. ferox}

The crude powdered plant material was defatted with petroleum ether and then subjected to soxhlet extraction to complete 20 cycles with chloroform. The chloroform extract thus obtained was filtered and concentrated on a water bath to obtain a thick paste.

\subsection{Exaction of Ayurvedic Shodhana-treated A. ferox}

The Ayurvedic Shodhana-treated drug material was defatted with petroleum ether and then subjected to soxhlet extraction to

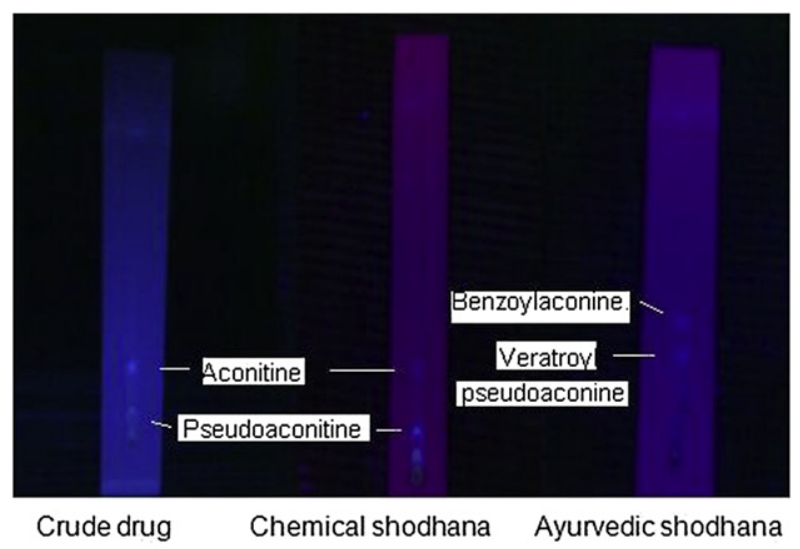

Fig. 2. Thin layer chromatography studies showing changes in chemistry of aconite root after and before different treatments. Stationary phase - Silica gel G; mobile phase - Benzene:Ethylacetate:Ethanol (15:4:1); detection - UV 366; running time: $8 \mathrm{~cm}$. complete 20 cycles with chloroform. The chloroform extract thus obtained was filtered and concentrated on a water bath to obtain a thick paste.

\subsection{Extraction of chemically treated A. ferox}

The powdered modified chemically treated Shodhana drug material was defatted with petroleum ether and then subjected to soxhlet extraction to complete 20 cycles with chloroform. The chloroform extract thus obtained was filtered and concentrated on a water bath to obtain a thick paste.

\subsection{Toxicity study}

For this study, Organisation for Economic Co-operation and Development (OECD) guideline 420 and some reference articles were followed. ${ }^{3}$ With prior approval from Institutional Animal Ethical Committee (Registration No.751/03/abc/CPCSEA), toxicity studies were conducted on female albino rats (150-200 gm). Sighting study was performed to determine appropriate dose for main study. Sighting study gave an appropriate selection of starting dose for the main study. Four groups were prepared for three extracts and one control. A total of five animals were taken for each group. The test substance was administered using a stomach tube. From the sighting study, the dose of $5 \mathrm{mg} / \mathrm{kg}$ was selected for Before Shodhana Extract and Lab Scale-Treated Extract. This dose of $5 \mathrm{mg} / \mathrm{kg}$ of Before Shodhana Extract and Lab Scale-Treated Extract

\section{Results: Sighting Study}

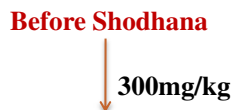

28 min death

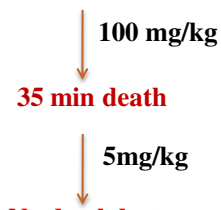

No death but uneasy, hiccups and whitish colour of eye

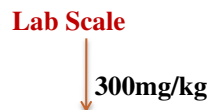

9:45 min death

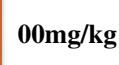

21:05 min death $5 \mathrm{mg} / \mathrm{kg}$

No death but uneasy and hiccups

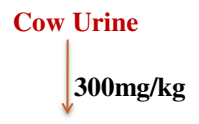

No deathh till $14^{\text {th }}$ day 2000mg/kg

No death till $10^{\text {th }}$ day But died $11^{\text {th }}$ day (delayed toxicity)

Fig. 3. Results of acute toxicity study (slighting study). 


\section{Results Main Study}

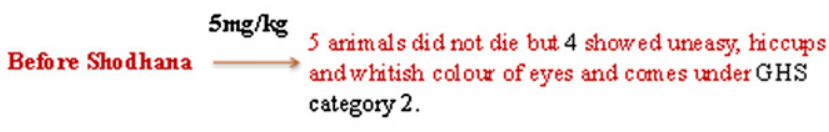

$$
\begin{array}{ll}
\text { Lab Scale } \stackrel{5 m g / k g}{5} \quad \begin{array}{l}
5 \text { arimals did not died but all showed uneasy, hiccups } \\
\text { and whitish coloux of eyes and comes under GHS } \\
\text { category } 2 .
\end{array}
\end{array}
$$

$$
\begin{array}{ll}
\text { Cow Urine } \stackrel{5 \mathrm{mg} / \mathrm{kg} \quad \text { All arimals survived and did not showed any sign of }}{\longrightarrow} \text { toxicity till } 14^{\text {th }} \text { day. } \\
\text { It means it is non-toxic. }
\end{array}
$$

Fig. 4. Results of acute toxicity study (main study).

showed evident toxicity while $300 \mathrm{mg} / \mathrm{kg}$ for Cow Urine-Treated Extract showed no toxicity till the 14th day. After the 14th day, the blood was withdrawn from the retro-orbital plexus of rats and pathological laboratory tests were performed that might be affected by the drug.

\subsection{Statistical analysis}

Data were analyzed using Dunnet test following one-way analysis of variance (ANOVA), using

GraphPad Prism 6, USA. $P>0.05$ was considered as nonsignificant.

\subsection{Chromatographic studies}

Thin layer chromatography (TLC) studies have been performed to observe changes in aconite alkaloids. ${ }^{4,5}$ The stationary phase employed was Silica gel G and mobile phase was Benzene:Ethylacetate:Ethanol (15:4:1). Detection was done in a UV cabinet using a $366-\mathrm{nm}$ lamp. The running distance was $8 \mathrm{~cm}$.

\section{Results and discussion}

Crude drug without any treatment, traditional Ayurvedic method Shodhana-treated drug material, and lab-scale chemically prepared cow urine-treated drug material were extracted with chloroform separately. These extracts were further evaluated by TLC to identify changes that might have occurred during Shodhana treatment. ${ }^{6,7}$ TLC studies have shown that pseudoaconitine and aconitine were converted into far less toxic substances veratroyl pseudoaconine and benzoylaconine respectively only in traditional Ayurvedic Shodhana (Fig. 2). As aconite is a poisonous drug in Ayurveda, it was decided to observe how Shodhana or chemically treated drug shows changes in its toxic effects by animal toxicity studies. Pathological parameters of animal blood samples were also evaluated. ${ }^{8,9}$ In slighting study, $300 \mathrm{mg} / \mathrm{kg}$ of Before Shodhana Extract (suspension of chloroform extract of Before Shodhana crude A. ferox) was given and monitored death occurred within $28 \mathrm{~min}$. Another animal was dosed at $100 \mathrm{mg} / \mathrm{kg}$ of Before Shodhana Extract, death occurred within $35 \mathrm{~min}$. Another animal again dosed at $5 \mathrm{mg} / \mathrm{kg}$, no death was observed but the animal was found to be uneasy, had hiccups, and there was whitish color in its eyes (Fig. 3).

In a sighting study, $300 \mathrm{mg} / \mathrm{kg}$ of Lab Scale-Treated Extract (suspension of chloroform extract of After Shodhana modified chemically treated $A$. ferox) was given and monitored death occurred within 9:45 min. Another animal was dosed at $100 \mathrm{mg} / \mathrm{kg}$ of Lab Scale-Treated Extract and death occurred within 21:05 min. Another animal was dosed at $5 \mathrm{mg} / \mathrm{kg}$, no death was observed but the animal was found to be uneasy and had hiccups.

In a sighting study, $300 \mathrm{mg} / \mathrm{kg}$ of Cow Urine-Treated Extract (suspension of chloroform extract of After Shodhana ayurvedically treated A. ferox) was given and monitored. No death occurred till the 14th day. The animal was found to be normal. Another animal was dosed at $2000 \mathrm{mg} / \mathrm{kg}$ of Cow Urine-Treated Extract, no death occurred till the 10th day but the animal died on the 11th day, which indicates delayed toxicity.

In the main study, the animals were observed for first $24 \mathrm{~h}$ at an interval of $30 \mathrm{~min}$. with special attention during $1 \mathrm{st} 4 \mathrm{~h}$, and daily thereafter, for a total of 14 days. Additional observations were also noted like behavior and color of eye (Fig. 4).

In the main study, $5 \mathrm{mg} / \mathrm{kg}$ of dose was defined for Before Shodhana Extract as per sighting study and given to one group of animals containing five animals each. The animals did not die but showed uneasiness, hiccups, and whitish color of eye. This was observed in all four animals which mean that the drug comes under Globally Harmonized System of Classification and Labeling of Chemicals (GHS) category 2.

In the main study, $5 \mathrm{mg} / \mathrm{kg}$ of dose was defined for Lab ScaleTreated Extract as per sighting study and given to second group of animals containing 5 animals each. The animals did not die but showed uneasiness and hiccups. This was observed in all four animals which means the drug comes under GHS category 2.

In the main study, $300 \mathrm{mg} / \mathrm{kg}$ of dose was defined for Cow Urine-Treated Extract as per sighting study and given to the third

\begin{tabular}{|c|c|c|c|c|c|c|}
\hline \multirow[t]{2}{*}{ Extract (mg/kg) } & \multirow[t]{2}{*}{ Death/recovery } & \multicolumn{5}{|l|}{ Lipid profile } \\
\hline & & Total cholesterol (mg\%) & HDL (mg\%) & LDL (mg\%) & VLDL (mg\%) & Triglyceride (mg\%) \\
\hline Control & No death till 14th day & $98.378 \pm 0.2668$ & $49.045 \pm 0.4601$ & $36.530 \pm 0.3724$ & $12.930 \pm 0.3679$ & $64.003 \pm 0.1841$ \\
\hline $\begin{array}{l}\text { Before Shodhana } \\
\quad 5 \mathrm{mg} / \mathrm{kg}\end{array}$ & $\begin{array}{l}\text { Death within } 28 \mathrm{~min} \text {. } \\
\text { at } 300 \mathrm{mg} / \mathrm{kg} .35 \mathrm{~min} \\
\text { at } 100 \mathrm{mg} / \mathrm{kg} \text { and no } \\
\text { death but uneasy, hiccups } \\
\text { and whitish color of eye } \\
\text { at } 5 \mathrm{mg} / \mathrm{kg}\end{array}$ & $150.00 \pm 2.614^{* * *}$ & $61.648 \pm 0.708^{* * *}$ & $70.268 \pm 1.876^{* * *}$ & $31.573 \pm 0.213^{* * *}$ & $156.69 \pm 0.217^{* * *}$ \\
\hline Lab-scale $5 \mathrm{mg} / \mathrm{kg}$ & $\begin{array}{l}\text { Death within 9:45 min } \\
\text { at } 300 \mathrm{mg} / \mathrm{kg} \mathrm{21:05} \mathrm{min} \\
\text { at } 100 \mathrm{mg} / \mathrm{kg} \text { and no death } \\
\text { but uneasy and hiccups } \\
\text { at } 5 \mathrm{mg} / \mathrm{kg}\end{array}$ & $147.75 \pm 3.326^{* * *}$ & $62.793 \pm 0.136^{* * *}$ & $56.703 \pm 3.217^{* * *}$ & $28.988 \pm 0.313^{* * *}$ & $153.98 \pm 0.401^{* * *}$ \\
\hline Cow urine $300 \mathrm{mg} / \mathrm{kg}$ & $\begin{array}{l}\text { No death till } 14 \text { th day } \\
\text { at } 300 \mathrm{mg} / \mathrm{kg}\end{array}$ & $101.98 \pm 0.0394^{\mathrm{ns}}$ & $81.230 \pm 0.115^{\mathrm{ns}}$ & $7.108 \pm 0.147^{* * *}$ & $18.603 \pm 0.201^{* * *}$ & $64.218 \pm 0.201^{\mathrm{ns}}$ \\
\hline
\end{tabular}
group of animal containing 5 animals each. All animals survived

Table 1

Results of biochemical parameters for toxicity study in female albino rats.

Mean $\pm \mathrm{SD} ; n=5$ in each group; ${ }^{* * *} P<0.001 ;{ }^{* *} P<0.01 ;{ }^{*} P<0.05 ;{ }^{\text {ns }} P>0.05$ when compared with control; HDL, LDL, VLDL. 
Table 2

Results of biochemical parameters for toxicity study in female albino rats.

\begin{tabular}{|c|c|c|c|c|c|}
\hline Extract (mg/kg) & Death/recovery & Urea (mg\%) & BUN (mg\%) & Creatinine (mg\%) & Albumin (mg\%) \\
\hline Control & No death till 14th days & $55.190 \pm 0.08371$ & $25.768 \pm 0.04049$ & $0.5250 \pm 0.02500$ & $2.800 \pm 0.04082$ \\
\hline $\begin{array}{l}\text { Before Shodhana } \\
\quad 5 \mathrm{mg} / \mathrm{kg}\end{array}$ & $\begin{array}{l}\text { Death within } 28 \mathrm{~min} \text {. } \\
\text { at } 300 \mathrm{mg} / \mathrm{kg} .35 \mathrm{~min} \\
\text { at } 100 \mathrm{mg} / \mathrm{kg} \text { and no } \\
\text { death but uneasy, hiccups } \\
\text { and whitish colour of eye } \\
\text { at } 5 \mathrm{mg} / \mathrm{kg}\end{array}$ & $90.225 \pm 0.058^{* * *}$ & $42.130 \pm 0.028^{* * *}$ & $0.8750 \pm 0.025^{* * *}$ & $4.750 \pm 0.028^{* * *}$ \\
\hline Lab scale $5 \mathrm{mg} / \mathrm{kg}$ & 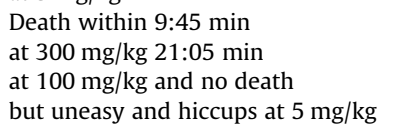 & $88.958 \pm 0.096^{* * *}$ & $41.538 \pm 0.044^{* * *}$ & $0.8500 \pm 0.028^{* * *}$ & $4.475 \pm 0.025^{* * *}$ \\
\hline Cow urine $300 \mathrm{mg} / \mathrm{kg}$ & No death till 14 th day at $300 \mathrm{mg} / \mathrm{kg}$ & $55.598 \pm 0.084^{*}$ & $25.843 \pm 0.154^{\mathrm{ns}}$ & $0.4000 \pm 0.000^{*}$ & $3.000 \pm 0.000^{*}$ \\
\hline
\end{tabular}

Mean \pm SD; $n=5$ in each group; ${ }^{* * *} P<0.001 ;{ }^{* *} P<0.01 ;{ }^{*} P<0.05 ;{ }^{n s} P>0.05$ when compared with control; BUN.

and did not show any sign of toxicity till the 14th day. It means it is non-toxic. Both Before Shodhana Extract and Lab Scale-Treated Extract significantly increased $(P<0.001)$ serum concentrations of total cholesterol, high-density lipoprotein (HDL), low-density lipoprotein (LDL), and very-low-density lipoprotein (VLDL), triglyceride, urea, blood urea nitrogen (BUN), creatinine, and albumin. Cow Urine-Treated Extract also significantly increased the HDL and VLDL but significantly decreased the LDL serum concentration of at-administration doses compared to control. However, it did not alter the total cholesterol, triglyceride, and BUN (Tables 1 and 2).

\section{Conclusion}

Though treatment with cow urine, cow milk, or cow dung is the traditional method of Shodhana, it may not be feasible or acceptable to all. The results of the present study suggest that the modified method of Shodhana is less efficient as compared to traditional Ayurvedic Shodhana process. TLC studies have shown that pseudoaconitine and aconitine were converted into far less toxic substances veratroyl pseudoaconine and benzoylaconine respectively only in traditional Ayurvedic Shodhana. TLC studies also revealed that chemical purification failed to convert toxic alkaloids to less toxic alkaloids. Chemical Shodhana process shows toxic effects on organs like liver, heart, and kidney. Thus, it is confirmed that the Ayurvedic Shodhana process is one of the powerful methods of detoxification and purification. Sincere attempts should be made to develop standardized and quality assured Ayurvedic Shodhana processes. Further studies are focused to evaluate other alternative Shodhana processes that use cow milk instead of cow urine.

\section{Conflicts of interest}

All authors have none to declare.

\section{References}

1. Sharadini AD, Urmila MT. Basic Principles of Ayurveda, Ayurveda Revisited. 1st ed Bombay: Popular Prakashan; 2000:90.

2. Bristow AW, Whitehead DC, Cockburn JE. Nitrogenous constituents in the urine of cattle, sheep and goats. J Sci Food Agric. 1992;59:387-394.

3. OECD Guideline for Testing of Chemicals. Acute Oral Toxicity 420 Adopted; 17th December 2001.

4. Stahl E. Thin Layer Chromatography. 2nd ed. Berlin: Springer; 2005:52-85.

5. Purushothaman KK, Chandrasekharan S. Alkaloids of Aconitum ferox. Phytochemistry. 1974;13:1975-1977.

6. Hanuman JB, Katz A. Isolation and identification of four norditerpenoid alkaloids from processed and unprocessed root tubers of Aconitum ferox. J Nat Prod. 1993;56:801-809.

7. Hanuman JB, Katz A. Isolation of quinolinones from ayurvedic processed root tubers of Aconitum ferox. Nat Prod Res. 1993;3:227-231.

8. Godkar PB. Clinical Biochemistry Principles \& Practice. 7th ed. Bombay, India: Bhalani. Publishing House; 2000:213-220.

9. Walker R, Edwards C. Clinical Pharmacy and Therapeutics. 3rd ed. Philadelphia: Churchill Livingstone; 2003:55. 